\title{
Photosynthesis in reproductive unicells of Ulva fasciata and Enteromorpha flexuosa: implications for ecological success
}

\author{
Kevin S. Beach*, Celia M. Smith, Teena Michael, Hyun-Woung Shin \\ Dept of Botany, University of Hawai'i, 3190 Maile Way, Honolulu, Hawai'i 96822, USA
}

\begin{abstract}
Photosynthetic performance of adult vegetative tissues is modified following the formation of free-swimming reproductive unicells by Ulva fasciata and Enteromorpha flexuosa. Comparisons of photosynthetic performance of adult haploid or diploid thalli versus gametes or zoospores (respectively) yield the following generalizations: (1) $P_{\max }$ (maximum net photosynthetic rate) for motile cells (e.g. gametes of $U$. fasciata and zoospores of E. flexuosa) can be equivalent to $P_{\max }$ of appropriate adult tissues when expressed on a chlorophyll $a(\mathrm{chl} a)$ or chl $a+b$ basis; (2) respiration rates for all motile cells were 1.5- to 6 -fold higher than rates for adult thalli when normalized to $\mathrm{chl}_{\text {: }}(3)$ as expected with increasing respiration rates, compensation irradiance $\left(I_{c}\right)$ and saturation irradiance $\left(I_{k}\right)$ also increased for all motile cell types; (4) chl $a: b$ ratios were lower in all motile cell types than in adult cells; (5) $P: R$ (photosynthesis:respiration) ratios were 3.3- to 7.7-fold lower in zoospores of U. fasciata and E. flexuosa respectively. Photosynthetic performance of settled zoospores of $U$. fasciata was more similar to the vegetative parent than to the free-swimming zoospores in terms of $I_{k}$ and $P_{\max }$ even with altered chl $a: b$ ratios. An unexpected finding was the increased in vivo absorbance in 490 to $550 \mathrm{~nm}$ range for reproductive tissues of $U$. fasciata only. This absorbance increase suggests a potential photoadaptation. This potential photoadaptation, coupled with alteration of the chl $a: b$ ratio, could allow reproductive unicells of $U$. fasciata to harvest light more readily for photosynthesis as part of the plankton when compared to zoospores of E. flexuosa. Such a difference between motile cells may enhance the competitive ability and subsequent ecological success of one over the other. High rates of $P_{\max }$ have the selective advantage of subsidizing high respiratory costs associated with motility in reproductive unicells while still allowing for rapid growth upon eventual attachment to the substrate. Comparably, species such as late successional kelps do not show this pattern and may represent a different photoadaptive strategy.
\end{abstract}

KEY WORDS: Photosynthesis - Zoospores - Gametes - Sporophytes - Gametophytes - In vivo absorption . Ulva fasciata. Enteromorpha flexuosa

\section{INTRODUCTION}

Photosynthetic capacities by planktonic reproductive unicells of many macroalgae are poorly known yet may reveal a diversity of exploitative strategies (sensu Grace 1990) and resulting ecological adaptations to the planktonic habitat, as has been found for life cycle phases of terrestrial plants (Grime 1979, Tilman 1982, Grace 1990). These exploitative strategy models have been applied to growth of planktonic algae (Tilman 1977) and adapted to photosynthetic and morphologi-

·E-mail: kevinb@hawaii.edu cal features of adult macroalgae (Littler \& Littler 1984, Steneck \& Dethier 1994), but no link has been made previously to possible strategies among algal reproductive units. The model of adaptive specialization by Grime (1979), which has been considered appropriate for macroalgal communities (Kain \& Norton 1990), recognizes 3 viable strategies: (1) exploitation, the ability to preemptively capture (exploit) limiting resources, is successful in regions of low stress (phenomena which restrict photosynthetic production; Grime 1979) and low disturbance (partial or total destruction of plant biomass; Grime 1979); (2) a ruderal strategy, the ability to withstand or recover from disturbance and still cap- 
ture limiting resources, occurs in response to low stress and high disturbance; and (3) stress tolerance, an adaptation for enduring suboptimal physiological conditions, occurs in response to high stress and low disturbance. Given the great diversity of exploitative strategies present among adult phases of life cycles, one might expect some diversity in strategies to be present among planktonic stages of macroalgal life cycles as well.

Planktonic stages are transient but crucial bottlenecks in macroalgal life cycles (Chapman 1984). The period of viability in planktonic life-cycle stages is enhanced when they can feed or have a yolk sac compared to nonfeeding larvae (Thorson 1950, Olsen 1985). Planktonic reproductive unicells of macroalgae that are photosynthetically competent upon release could similarly extend a 'window of viability', leading to increased success in settlement and recruitment. Photoadaptive strategies for particular light regimes common to coastal environments may further enhance the success of reproductive unicells over those without such a capability. The photosynthetic characteristics of only a few reproductive unicells of temperate brown algae have been characterized (McLachlan \& Bidwell 1978, Amsler \& Neushul 1991), and other algal groups with markedly different photosynthetic pigments, lifecycle strategies, and latitudinal distributions remain unexamined.

Planktonic unicells of benthic macroalgae have commonly been reported to have brief viability, $24 \mathrm{~h}$ to $11 \mathrm{~d}$ under laboratory conditions (Kain 1964, Hoffmann \& Camus 1989, Santelices 1990). This ephemeral nature has been partially attributed to immature chloroplasts in newly released propagules (McBride \& Cole 1971, Toth 1976, Borowitzka 1978, Santelices 1990), resulting in greatly reduced photosynthetic rates (Kain 1964, Santelices 1990). In only 2 studies to date, net positive photosynthesis has been demonstrated for algal reproductive unicells. These are zoospores of 4 genera characterized by a heteromorphic alternation of generations and sporic meiosis (Amsler \& Neushul 1991) and Fucus serratus gametes, an intertidal alga with gametic meiosis (McLachlan \& Bidwell 1978). In both cases photosynthetic capacity is markedly lower than rates for adult macroalgae rates (Littler \& Arnold 1982).

Species of the weedy genera Ulva and Enteromorpha are generally the first macroalgae to colonize open substrate and are considered troublesome fouling organisms. This ecological role is attributed to their simple adult morphologies and to their fecundity. Propagule release resulting from a sporic meiosis life cycle (Fig. 1) may occur daily (Shin pers. obs.) for species in low latitude populations. In Ulva spp. 20 to $60 \%$ of overall biomass is allocated monthly to reproduction depending upon season (Smith 1947, Niesem-

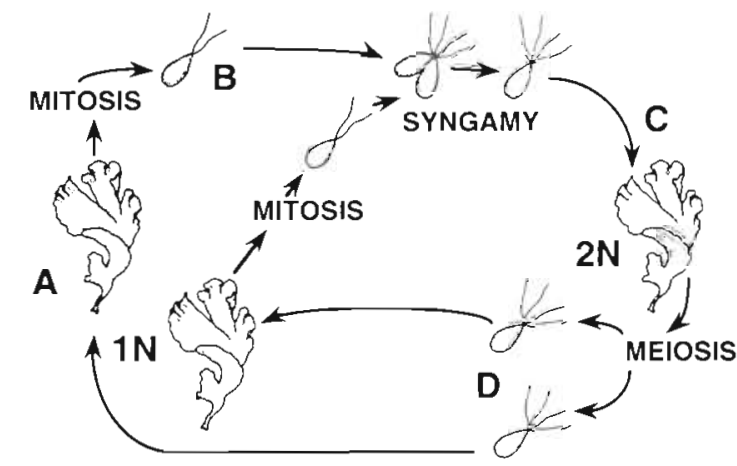

Fig. 1. Ulva fasciata and Enteromorpha flexuosa. Typical sporic meiosis life cycle. A: male and female gametophyte; B: biflagellate gamete; $C$ : sporophyte $D$ : quadriflagellate zoospore. $1 \mathrm{~N}$ : haploid; $2 \mathrm{~N}$ : diploid

baum 1988, Shin pers. obs.). Spore release in intertidal Ulva and Enteromorpha species is driven by tidal/ lunar rhythms (Smith 1947, Christie \& Evans 1962, Sawada 1978). Reproductive unicells of Enteromorpha intestinalis can remain motile for up to $8 \mathrm{~d}$ after release if subjected to continuous irradiance and agitation; reduction in the irradiance period corresponds to a shortened period of motility (Jones \& Babb 1968). Even low rates of photosynthesis by spores or gametes of Ulva and Enteromorpha species could extend both their viability and dispersal range while subsequently contributing to the success of these species over taxa with shorter-lived or physiologically less-competent reproductive cells.

We sought here to evaluate aspects of the photosynthetic and respiratory competence of different stages in the life cycle of Ulva fasciata and Enteromorpha flexuosa (Fig. 1). Specifically, we asked: (1) What physiological changes resulted from the formation of reproductive unicells from vegetative cells? (2) Are gametes and zoospores similar in terms of photosynthetic performance and respiratory demands? (3) Do closely allied genera from similar physical environments produce reproductive unicells that are physiologically similar? (4) How do the photosynthetic performances of these subtropical unicells compare to those reported for unicells from other macroalgae? (5) Does apparent photoadaptation by these unicells indicate an overall adaptive strategy or strategies that may contribute to patterns in algal community composition and development?

\section{MATERIALS AND METHODS}

Reproductive and vegetative thalli of intertidal UIVa fasciata Delile and Enteromorpha flexuosa (Wulfen) $\mathrm{J}$. Agardh were collected at Ka'alawai and Kailua, O'ahu, Hawai'i, USA, respectively, from 19 July to 15 
October 1993. Individuals were washed free of macroscopic epiphytes and maintained separately in $0.2 \mu \mathrm{m}$ filtered seawater (FSW) at $25^{\circ} \mathrm{C}$ under a 16:8 h light: dark cycle $\left(50 \mu \mathrm{mol}\right.$ quanta $\mathrm{m}^{-2} \mathrm{~s}^{-1}$, provided by fluorescent lamps).

In vivo absorption and 4th derivative spectra analyses. In vivo absorption spectra were obtained using a Shimadzu UV Vis-2101 spectrophotometer with a $150 \mathrm{~mm}$ Shimadzu integrating sphere attachment on algal tissues of dimensions $1.3 \times 3.0 \mathrm{~cm}$. Spectra were obtained by placing a non-overlapping layer of vegetative or gamete-/zoospore-bearing tissue, which had gently been blotted dry, between 2 glass slides. The spectral scans ( $<60 \mathrm{~s}$ in duration) were acquired at room temperature and normalized at $750 \mathrm{~nm}$. The spectrum sampling interval was set at $0.2 \mathrm{~nm}$. The 4 th derivative spectra were generated with the algorithms provided by the manufacturer's software PC revision 2.2 with a lambda of 16 . By performing spectral analyses on intact tissues and not comparing intact tissues with dense reproductive unicell suspensions, differences in the 'package effect' between the reproductive and vegetative were minimized but not totally eliminated (because of differential compartmentalization between vegetative cells and the reproductive unicells resulting from meiotic or mitotic divisions). Typically, motile reproductive unicells were released within $0.5 \mathrm{~h}$ of spectral analysis, confirming the reproductive maturity of the tissues analyzed and the noninvasive nature of this approach.

Release and handling of motile cells for physiological measurements. Zoospores from adult sporophytes of Ulva fasciata or Enteromorpha flexuosa were released synchronously by rehydration of partially desiccated thalli within $6 \mathrm{~h}$ of field collection of the adult material. Care was taken to examine only motile gametes or zoospores from single individuals within $0.5 \mathrm{~h}$ of release. For postsettlement photosynthetic measurements, zoospores were induced to settle at room temperature onto $2.0 \mathrm{~cm}^{2}$ nytex mesh utilizing a low photon flux (25 $\mu$ mol quanta $\mathrm{m}^{-2} \mathrm{~s}^{-1}$ ) white light, provided by a dissecting lamp, focused on the mesh. The nytex mesh was soaked in FSW for $24 \mathrm{~h}$ before zoospore settlement. Zoospores were allowed to settle onto the mesh for $3 \mathrm{~h}$ and then physiologically evaluated after a brief rinse to facilitate removal of nonattached zoospores. Three hours of settlement time on glass slides produced $>99 \%$ zoospore settlement with flagellar detachment.

Gamete formation in Ulva fasciata was similarly induced in fertile thalli by a $12 \mathrm{~h}$ partial submergence in $100 \mathrm{ml}$ FSW. Synchronous release of gametes was initiated by completely rehydrating thalli. Syngamy was minimized by maintaining and running trials on isolated individual thalli and their gametes.
Densities of gametes and zoospores were maintained between $2.5 \times 10^{6}$ to $3.0 \times 10^{7}$ cells $\mathrm{ml}^{-1}$ for photosynthesis and respiration measurements. Shelf shading and reproductive unicell settlement were minimized by a high but nondamaging stirring speed in the electrode chamber. After photosynthetic trials, unicells were evaluated microscopically for visible cell damage (e.g. disruption). A $0.5 \mathrm{ml}$ aliquot of each cell suspension was preserved in $4.0 \%$ buffered formalin at the beginning of each trial for subsequent determination of cell density. During the period of this study we were unable to obtain sufficient numbers of Enteromorpha flexuosa gametes or settled zoospores for characterization.

Physiological measurements of adult thalli. Vegetative tissue disks $\left(0.37 \mathrm{~cm}^{2}\right)$ of Ulva fasciata thalli were sampled with a cork borer from apical regions just below the marginal reproductive tissue. Vegetative samples $\left(0.25 \mathrm{~cm}^{2}\right)$ from Enteromorpha flexuosa were obtained from the apical vegetative tissue located below the apical sporogenous zone. Preliminary microscopic evaluation was utilized to differentiate vegetative and reproductive tissues. Vegetative samples were attached to a modified chamber seal of the oxygen electrode (Smith \& Berry 1986) by nytex mesh and maintained in FSW under $50 \mu \mathrm{mol}$ quanta $\mathrm{m}^{-2} \mathrm{~s}^{-1}$. Other specifics of these measurements are discussed below.

Photosynthesis and respiration measurements. Net photosynthesis was measured as oxygen exchange using a water jacketed Clark-type oxygen electrode (Rank Brothers, Cambridge, UK). Temperature was maintained at $25 \pm 1^{\circ} \mathrm{C}$ via a Neslab RTE-110 temperature controlled water bath. Illumination was provided by a Kodak Ektagraphic III E slide projector with a $300 \mathrm{~W}$ tungsten halogen lamp and photon flux was varied from 0 to $2500 \mu \mathrm{mol}$ quanta $\mathrm{m}^{-2} \mathrm{~s}^{-1}$ with neutral density filters. To minimize carbon limitation the FSW was augmented to $20 \mathrm{mM} \mathrm{NaHCO}_{3}{ }^{-}$above ambient levels in vegetative and reproductive unicell trials. Chlorophyll (chl) concentrations were determined utilizing $N, N$-dimethylformamide extraction (Moran \& Porath 1980) and a Hewlett Packard 5428 A Diode array spectrophotometer. Calculations were based on the equations of Inskeep \& Bloom (1985).

Photosynthetic parameters of compensation irradiance $\left(I_{c}\right)$, quantum efficiency $(\alpha)$ and maximum photosynthetic rate $\left(P_{\max }\right)$ were determined by linear regression of the linear light-limited and linear lightsaturated portions of the photosynthesis versus irradiance curves. Saturation irradiance $\left(I_{k}\right)$ was estimated by the irradiance at the intersection of the abovementioned lines. Respiration was determined by averaging pre-and post-trial dark treatments.

Statistical analyses. The subsequent statistical analyses were carried out using Minitab version 8.2 
(Minitab, Inc.). Normality was assessed with a test equivalent to Shapiro-Wilk test with an $\alpha$ of 0.05 (Minitab Reference Manual 1991). When normally distributed, comparisons of gametophyte to gametes, sporophyte to zoospores and sporophyte to settled zoospores were made with pairwise $t$-tests (Zar 1984). If normality was in question either a pairwise Wilcoxon test (when data were symmetrical) or a pairwise Sign test (when symmetry was in question) were used (Zar 1984).

\section{RESULTS}

\section{Gametophyte and gametes: physiological features}

When normalized to $\mathrm{chl} a+b$, values for respiration, $I_{c} I_{k}$, the ratio of $P_{\max }$ (net) to respiration ( $P: R$ ratio) and $c h l a: b$ ratio for gametes of Ulva fasciata were signifi- cantly different to those of gametophytes (Table 1). Gametes of $U$. fasciata attained rates of $P_{\max }$ and $\alpha$ similar to those of haploid thalli (Table 1)

\section{Sporophyte and zoospore physiological features}

Adult sporophytes of Ulva fasciata differed physiologically from corresponding zoospores in that chl $a+b$ specific $I_{c} I_{k}$ and respiration rates were significantly higher for zoospores than for parental tissues (Table 2). The values of $\alpha, P_{\max }$ and $P: R$ ratio were all markedly lower for zoospores of $U$. fasciata when compared with adults (Table 2) but $P: R$ ratio remained greater than 1.

Photosynthesis and respiration by zoospores of Enteromorpha flexuosa differed from comparable processes by adult sporophytes in ways similar to those

Table 1 Ulva fasciata. Comparison of gametophyte and gamete $P$ vs $I$ curve parameter means [standard errors (SE) in parenthe-

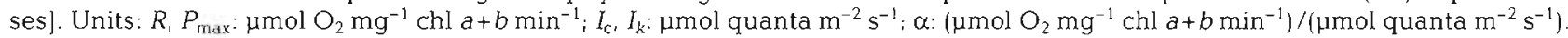
Pairwise comparisons of $P$ vs $I$ parameters between life cycle stages are $t$-tests unless otherwise noted. nd: no difference ${ }^{~}$ significant difference. n: number of samples

\begin{tabular}{|c|c|c|c|c|c|c|c|c|}
\hline Life cycle stage & $\mathrm{n}$ & $R$ & $I_{c}$ & $I_{k}$ & $\alpha$ & $P_{\max }$ & $P: R$ ratio & Chl a: $b$ ratio \\
\hline Gametophyte & 12 & $\begin{array}{c}0.55 \\
(0.10)\end{array}$ & $\begin{array}{l}27.1 \\
(3.1)\end{array}$ & $\begin{array}{l}162.9 \\
(12.5)\end{array}$ & $1.17 \times 10^{-2 \mathrm{a}}$ & $\begin{array}{c}1.84 \\
(0.22)\end{array}$ & $\begin{array}{c}4.78 \\
(0.92)\end{array}$ & $\begin{array}{c}1.72 \\
(0.06)\end{array}$ \\
\hline Gamete & 12 & $\begin{array}{l}1.16 \\
(0.10)\end{array}$ & $\begin{array}{l}99.5 \\
(7.0)\end{array}$ & $\begin{array}{l}288.3 \\
(22.6)\end{array}$ & $9.8 \times 10^{-3} \mathrm{~d}$ & $\begin{array}{c}1.62 \\
(0.22)\end{array}$ & $\begin{array}{c}1.44 \\
(0.16)\end{array}$ & $\begin{array}{c}1.37 \\
(0.06)\end{array}$ \\
\hline $\begin{array}{l}\text { Gametophyte vs } \\
\text { gamete pairwise mean }\end{array}$ & 12 & $\begin{array}{c}0.61 \\
(0.11)\end{array}$ & $\begin{array}{r}-72.4 \\
\quad(5.6)\end{array}$ & $\begin{array}{r}-125.4 \\
(21.3)\end{array}$ & $1.8 \times 10^{-3}$ & $\begin{array}{c}0.22 \\
(0.23)\end{array}$ & $\begin{array}{l}3.34 \\
(0.89)\end{array}$ & $\begin{array}{c}0.35 \\
(0.04)\end{array}$ \\
\hline p-value & & $0.0002^{\circ}$ & $<0.0000^{\circ}$ & $<0.0000^{\circ}$ & $0.073 \mathrm{nd}^{\mathrm{b}}$ & $0.37 \mathrm{nd}$ & $0.0016^{\circ}$ & $<0.0000^{\circ}$ \\
\hline
\end{tabular}

Table 2. Ulva fasciata. Comparison of sporophyte, zoospore and settled zoospore $P$ vs $l$ curve parameter means [standard errors (SE) in parentheses]. Units as in Table 1

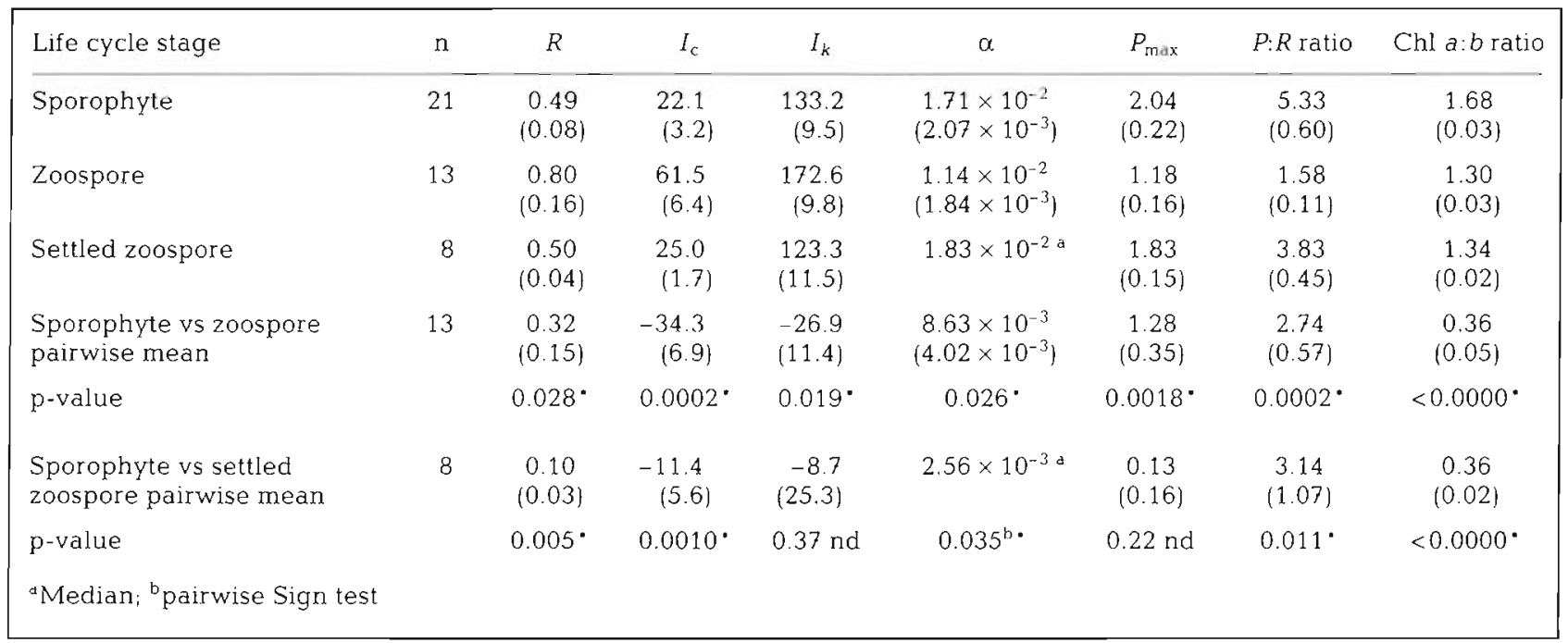


Table 3. Enteromorpha flexuosa. Comparison of sporophyte and zoospore $P$ vs I curve parameter means [standard errors (SE) in parentheses]. Units as in Table 1

\begin{tabular}{|c|c|c|c|c|c|c|c|c|}
\hline Life cycle stage & $\mathrm{n}$ & $R$ & $I_{\mathrm{c}}$ & $I_{k}$ & $\alpha$ & $P_{\sin a x}$ & $P: R$ ratio & Chl a:b ratio \\
\hline Sporophyte & 5 & $\begin{array}{c}0.44 \\
(0.46)\end{array}$ & $\begin{array}{l}32.8 \\
(6.6)\end{array}$ & $\begin{array}{l}195.6 \\
(15.2)\end{array}$ & $\begin{array}{c}1.28 \times 10^{-2} \\
\left(1.03 \times 10^{-3}\right)\end{array}$ & $\begin{array}{l}2.00 \\
(0.09)\end{array}$ & $\begin{array}{c}4.70 \\
(0.48)\end{array}$ & $\begin{array}{c}1.60 \\
(0.04)\end{array}$ \\
\hline Zoospore & 5 & $\begin{array}{c}2.49 \\
(3.56)\end{array}$ & $\begin{array}{l}393.8 \\
(78.9)\end{array}$ & $\begin{array}{l}620.2 \\
(75.3)\end{array}$ & $\begin{array}{c}6.28 \times 10^{-4} \\
\left(7.32 \times 10^{-5}\right)\end{array}$ & $\begin{array}{l}1.30 \\
(0.27)\end{array}$ & $\begin{array}{l}0.58 \\
(0.17)\end{array}$ & $\begin{array}{c}1.24 \\
(0.06)\end{array}$ \\
\hline $\begin{array}{l}\text { Sporophyte vs zoospore } \\
\text { pairwise mean }\end{array}$ & 5 & $\begin{array}{c}2.05 \\
(0.35)\end{array}$ & $\begin{array}{r}-361.0 \\
(77.7)\end{array}$ & $\begin{array}{r}-424.6 \\
(86.1)\end{array}$ & $\begin{array}{c}1.22 \times 10^{-2} \\
\left(1.03 \times 10^{-3}\right)\end{array}$ & $\begin{array}{c}0.70 \\
(0.35)\end{array}$ & $\begin{array}{c}4.12 \\
(0.60)\end{array}$ & $\begin{array}{l}0.27 \\
(0.04)\end{array}$ \\
\hline p-value & & $0.0021^{\circ}$ & $0.0049^{\circ}$ & $0.0039^{\circ}$ & $0.0001^{\circ}$ & $0.058 \mathrm{nd}$ & $0.0011^{\circ}$ & $0.001^{\circ}$ \\
\hline
\end{tabular}

observed for UIva fasciata (Table 3), yet the magnitude of change in the transition from adult thallus to zoospores appeared to differ between $U$. fasciata and E. flexuosa (Tables $2 \& 3$ ). Respiration rates, $I_{c}$ and $I_{k}$ were 3-, 6- and 3-fold higher respectively for zoospores of E. flexuosa when compared with zoospores of $U$. fasciata. The value of $\alpha$ and $P: R$ ratio were 21 - and 3 -fold lower, respectively, for zoospores of E. flexuosa when compared with zoospores of $U$. fasciata. The $P$ : $R$ ratio for zoospores of E. flexuosa was substantially less than 1 (0.58). The photophysiological responses of adult thalli of E. flexuosa were similar to $U$. fasciata adults (Tables 2 \& 3).

\section{Sporophyte and recently settled zoospore: physiological features}

Rates of respiration and values of $I_{c}$ for recently settled zoospores of Ulva fasciata were significantly greater than those observed for corresponding adult thalli (Table 2). The $P: R$ ratio decreased significantly in the settled zoospore state compared to the vegetative state. The values of $I_{k}$ and $P_{\max }$ for settled zoospores of $U$. fasciata were indistinguishable from adult thalli (Table 2). The median value of $\alpha$ for settled zoospores was significantly less than that of the adult thalli on a pairwise basis (Table 2).

Comparisons between vegetative tissue and reproductive unicells were reported on a chl $a+b$ basis only. Similar differences were seen on a chl a basis except for $\alpha$. Because of the pronounced differences in chl $a: b$ ratios between stages, chl $a+b$ was chosen as a more reliable measure on which to base photosynthetic parameters in this study. For ease of future comparisons, $P_{\max }$ rates normalized to $\mathrm{chl} a$, fresh weight, dry weight, and surface area are reported in Table 4. Because of high cell densities required for this type of physiological evaluation, self-shading in the oxygen electrode was a concern. No significant relationship was found linking cell density and the values of $I_{c}$ or $I_{k}$ for Ulva fasciata and Enteromorpha flexuosa (data not shown). These findings suggest that within the range of cell densities used in this study, no artifacts can be attributable to self-shading. Additionally, the most marked change observed for any tissues was the increase in respiration rates of unicells with concomitant increases in values for $I_{c}$ and $I_{k}$. Respiration is clearly not influenced by self-shading.

\section{In vivo absorption features and 4 th derivative spectra analysis}

Both in vivo absorption and 4 th derivative spectra of Ulva fasciata and Enteromorpha flexuosa were in close agreement with data from $U$. expansa and $U$. taeniata (Smith \& Alberte 1994). In vivo absorption spectra of sporophytes and gametophytes of $U$. fasciata exhibited consistent changes in pigmentation with reproductive unicell formation (Fig. 2A, B). The relative magnitudes

Table 4. Ulva fasciata and Enteromorpha flexuosa. Mean maximum photosynthetic rates (SE in parentheses) of vegetative tissues normalized to chl $a$, fresh weight, dry weight, and surface area. n: number of samples; nd: not determined

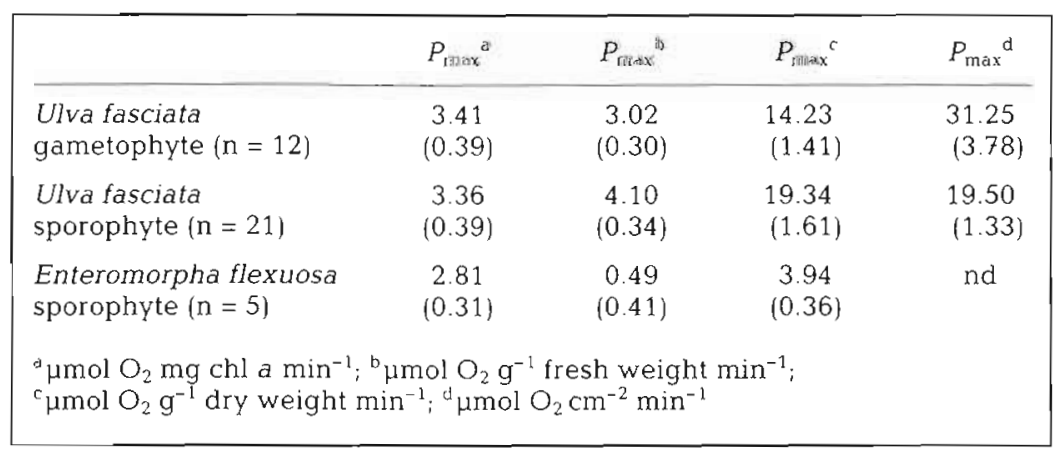


of the red absorption peaks at 680 (chl a) and 650 (chl b) nm and Soret bands revealed the elevated chl $b$ content of reproductive tissues compared to vegetative tissues (Fig. 2A, B) confirming the results of pigment extraction (Tables $1 \& 2$ ). The 490 to $540 \mathrm{~nm}$ region of the spectra revealed an increase in absorption by both zoospore and gamete producing tissue compared with parental tissue.

Fourth derivative deconvolution of this spectral region demonstrated that the $490 \mathrm{~nm}$ peak of both gametophyte and sporophyte thalli of Ulva fasciata, attributed to carotenoid absorption (Smith \& Alberte 1994), had shifted $12 \mathrm{~nm}$ to longer wavelengths (Fig. 2A, B) and may represent the presence of a novel pigment or an increase in the content of a carotenoid species in these reproductive tissues. Efforts to identify the specific changes in carotenoid pigment composition from vegetative to reproductive tissues in U. fasciata are underway.

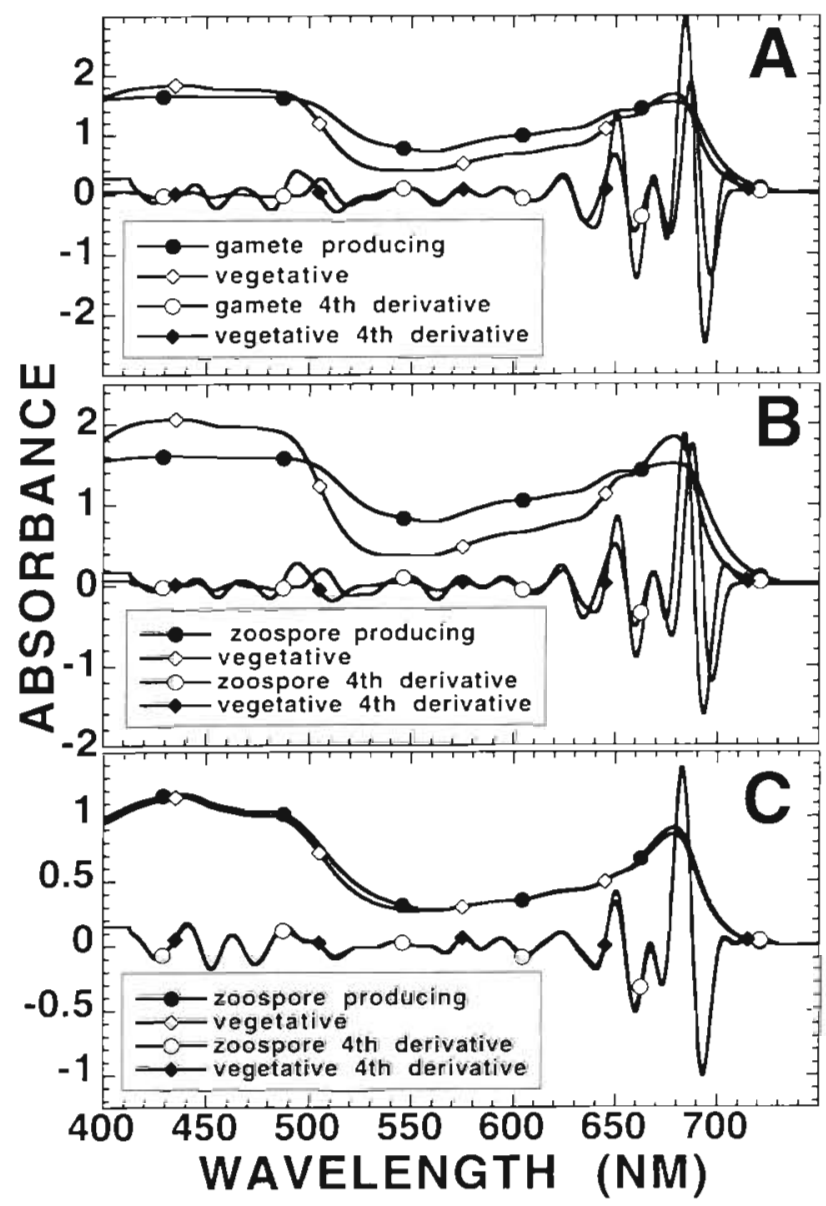

Fig. 2. Ulva fasciata and Enteromorpha flexuosa. Mean in vivo absorption and 4 th derivative spectra of vegetative and reproductive tissues of (A) $U$. fasciata gametophyte $(\mathrm{n}=5$ ). (B) U. fasciata sporophyte $(\mathrm{n}=8)$ and, (C) E. flexuosa sporophyte $(n=7)$
In vivo spectral features of vegetative sporophyte and zoospore producing thaili of Enteromorpha flexuosa were virtually identical. E. flexuosa had a consistent but less pronounced change than Ulva fasciata in the relative magnitudes of the in vivo absorption peaks at 680 and $650 \mathrm{~nm}$ (Fig. 2C). Pigment analyses confirmed that reproductive tissue had a lower chl $a: b$ ratio than vegetative tissue (Table 3 ). The 4 th derivative spectra of vegetative and reproductive $E$. flexuosa were identical (Fig. 2C) and did not exhibit a change in the $490 \mathrm{~nm}$ spectral region as seen in $U$. fasciata (Fig. 2A, B).

\section{DISCUSSION}

Reproductive unicells of Ulva fasciata and Enteromorpha flexuosa demonstrated substantial rates of photosynthesis in contrast to that observed in kelp zoospores (Amsler \& Neushul 1991). Gametes and zoospores showed elevated rates of respiration when compared with adult thalli, which might be attributable to increased metabolic demands of motility. Values of $I_{c}$ and $I_{k}$ increased in all cases, while $P_{\max }$ values were lower only for zoospores of $U$. fasciata. Overall, we observed similar results for (1) in vivo absorption spectra for gamete and zoospore producing thalli of $U$. fasciata, and (2) 4 th derivative spectra of gamete producing and zoospore producing thalli of $U$. fasciata. Yet photosynthetic performance of $U$. fasciata gametes and zoospores differed in their physiological divergence from parental thalli. While vegetative gametophytes and sporophytes were similar in all their photosynthetic attributes, gametes of $U$. fasciata demonstrated values for $P_{\max }$ and $\alpha$ that were equal to those of vegetative gametophytes. Zoospores of $U$. fasciata did not reveal similar rates or efficiencies as in vegetative sporophytes. Thus, a remarkable degree of difference can be seen among motile cell types for this species.

Although the trends of photophysiological change with zoospore formation are similar for both species, there are marked differences even among cell types. The respiration rate and related values for $I_{c}$ and $I_{k}$ were all modified to a greater degree with zoospore formation in Enteromorpha flexuosa than in Ulva fasciata. These changes may be attributed solely to increased respiration rates but, for both species' zoospores, $\alpha$ was also markedly altered (200-fold decrease in E. flexuosaj. A decrease in $\alpha$ is usually interpreted as a decreased efficiency of the photosynthetic apparatus. This decrease may occur at the site of carbon fixation and/or with modification in the size and/or number of photosynthetic units in photosystem I and/or photosystem II. The differ- 
ence in these photosynthetic parameters resulted in a marked difference in the daily net carbon balance between the zoospores of these species (calculated as in Matta \& Chapman 1991). Zoospores of $U$. fasciata have a net positive carbon balance $1+6.6 \mu \mathrm{mol} C$ fixed $\mathrm{mg}^{-1}$ chl $a+b \mathrm{~d}^{-1}$ with an $H_{\text {sat }}$ (hours at saturating irradiance) of $10 \mathrm{~h}$ ) while zoospores of E. flexuosa were markedly negative $(-1318 \mu \mathrm{mol} C$ fixed $\mathrm{mg}^{-1} \mathrm{chl} a+b \mathrm{~d}^{-1}$ with the same photoperiod).

The difference in the photosynthetic performance between zoospores of Enteromorpha flexuosa and UIVa fasciata may be attributable to the observed changes in the relative pigment composition of these 2 algae. Both species decreased their chl $a: b$ ratio with zoospore formation but this change occurred to a lesser degree in E. flexuosa. U. fasciata appeared to have also procuced an increased relative amount of carotenoids in zoospore producing portions of the sporophyte. These pigment changes may result in a broadening of the absorbed photosynthetically active radiation (PAR) into the blue-green region for $U$. fasciata zoospores and gametes. This is the light quality typical of coastal waters (Jerlov 1968).

Upon release several important hydrodynamic processes influence the distribution of reproductive unicells. Surface currents away from the sites of potential settlement and/or other compatible gametes can reduce the probability of settlement (Roughgarden et al. 1988). With the capability of satisfying metabolic and motility demands by efficient photosynthesis, the temporal window during which fusion and/or settlement may be accomplished could be extended. This possibility could increase the ecological range of a particular population and would increase potential for outcrossing among at least local populations. Downwelling currents would similarly alter zoospore and gamete distribution. Reproductive unicells that have the capacity to reach $P_{\max }$ values at lower irradiance levels (e.g. have a low $I_{c}$ and $I_{k}$ values) and have the capability to harvest the quality of light present in turbid coastal waters may prosper in these conditions while those requiring higher irradiance levels to reach $I_{c}$ and $I_{k}$ may not remain viable when transported away from near-surface waters. Overall, this relative-low light photoadaptation [I $I_{k}: 172 \mu \mathrm{mol}$ quanta $\mathrm{m}^{-2} \mathrm{~s}^{-1}$ (Ulva fasciata) vs $620 \mu \mathrm{mol}$ quanta $\mathrm{m}^{-2} \mathrm{~s}^{-1}$ (Enteromorpha flexuosa)] would allow the reproductive unicells of $U$. fasciata to exploit light more successfully in their planktonic habitat compared to unicells of E. flexuosa.

Within 3 h of settlement, the photophysiology of Ulva fasciata zoospores adjusted to a state closer to the vegetative adult thalli than that of free-swimming zoospores. Upon settlement respiration and $I_{c}$ were only slightly elevated above values of the parental thalli. At the same time, the values of $P_{\max }$ and $I_{k}$ were indistinguishable from parental thalli. The value of $\alpha$ remained lower than $\alpha$ of parental thalli but was greater than $\alpha$ observed for zoospores of $U$. fasciata supporting the hypothesis that the shift seen between vegetative adults and zoospores was not solely caused by motility. With settlement, the metabolic demands of motility are lost but other metabolic process associated with attachment may contribute to the slightly elevated respiration levels. All of these changes took place without an immediate alteration of the chl $a: b$ ratio to levels associated with vegetative tissues.

Even with the limited number of species that have been examined in this manner, 4 kelp species (Amsler \& Neushul 1991), 1 fucoid alga (McLachlan \& Bidwell 1978), and 2 ulvalean species (this study), some comparisons can be made regarding photosynthetic and respiration rates by reproductive unicells in these 2 groups. [Direct comparisons to McLachlan \& Bidwell (1978) are not possible because of the different techniques and scope of questions addressed by the different workers.] $I_{\kappa}, I_{k}, P_{\max }\left(\right.$ cell $^{-1}$ and chl $\left.a^{-1}\right)$, chl a cell ${ }^{-1}$, and respiration are markedly lower for these select phaeophyte algae when compared to Ulva fasciata and Enteromorpha flexuosa (Table 5). This disparity may reflect evolutionary differences. Additionally, the light

Table 5. Comparison of $P$ vs $I$ parameters for reproductive unicells of subtropical Ulvales and temperate Laminariales. 2.0 ml sample volume assumed for photosynthesis and respiration determinations for kelps (C. Amsler pers. comm.). fg chl a cell ${ }^{-1}$

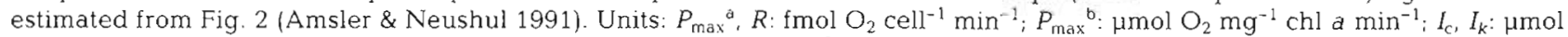
quanta $\mathrm{m}^{-2} \mathrm{~s}^{-1}$

\begin{tabular}{|llllrrrr|}
\hline & $P_{\max }{ }^{\mathrm{d}}$ & $P_{\max }{ }^{\mathrm{b}}$ & $R$ & $I_{c}$ & $I_{k}$ & fg chl a cell $^{-1}$ & Source \\
\hline Ulva fasciata gametes & 0.58 & 2.79 & 0.59 & 100 & 288 & 300 & This study \\
Ulva fasciata zoospores & 1.27 & 2.09 & 0.86 & 62 & 173 & 753 & This study \\
Enteromorpha flexuosa zoospores & 0.63 & 2.51 & 0.98 & 394 & 620 & 243 & This study \\
Macrocystis pyrifera zoospores & 0.0034 & 0.098 & 0.27 & 46 & 59 & 27 & Amsler \& Neushul (1991) \\
Nereocystis luetkeana zoospores & 0.0057 & 0.10 & 0.0038 & 47 & 77 & 58 & Amsler \& Neushul (1991) \\
Laminaria farlowii zoospores & 0.0047 & 0.039 & 0.0040 & 32 & 41 & 120 & Amsler \& Neushul (1991) \\
Pterygophora califonica zoospores & 0.012 & 0.038 & 0.0045 & 23 & 65 & 337 & Amsler \& Neushul (1991) \\
\hline
\end{tabular}


environment seen by sporophylls of temperate lower intertidal to subtidal kelps (Reed \& Foster 1984) is substantially different to that of the irradiance field for subtropical ulvalean algae. The above-mentioned photosynthetic differences are proposed to be a selective response by reproductive unicells, implemented at the level of photosynthetic features, for increased success in coastal ecological niches. Physiological studies in deeply shaded terrestrial habitats have suggested evolutionary mechanisms of conserving energy such as low respiratory rates may be important in maintaining a carbon balance (Grime 1979). The reproductive unicells of kelps and other late successional species may benefit from a low-light-tolerant strategy in that by being adapted to low light conditions, reproductive unicells may persist in the environment in which they are released and settle. Pioneer species can attribute part of their ecological success to a persistent pool of motile cells that can rapidly colonize cleared or new substrate (Doty 1967). A longer lived pool of motile cells that can contribute to their own metabolic demands insures this success. This ulvalean strategy exploits light to enhance the success of weedy benthic algae as pioneer species.

Contrary to prior generalizations, some reproductive unicells can rapidly attain photosynthetic rates equal to those observed in adult thalli. The selective advantage of photosynthetic capacity and photoadaptation in algal reproductive unicells for colonization, adult zonation and individual competitive ability remain largely unexplored. These are however, important steps in establishment of an algal community that may be markedly influenced by the photosynthetic potential exhibited by these important early settlers. The photosynthetic potential differences observed between different free-swimming stages of Ulva fasciata and Enteromorpha flexuosa suggest that evolutionarily and ecologically allied species can have markedly different photoadaptive strategies. The photophysiological differences observed between reproductive unicells of opportunistic ulvalean algae and kelps characteristic of late successional communities are proposed to be representative of exploitative and stress tolerant exploitation strategies respectively. These strategies may be seen in planktonic unicells of many benthic algae with similar macroalgal niches and adult exploitation strategies.

Acknowledgements. We are very grateful to R. S. Alberte for his beneficial discussion and suggestions. The authors thank the anonymous reviewers as well as L. Hodgson and B. Santelices whose comments greatly improved the manuscript The authors also gratefully recognize the support of the Office of Naval Research whose assistance made this research possible. ONR grants \# N00014-92-J-1700 and N00014-92-J-1852 to C.M.S.

\section{LITERATURE CITED}

Amsler CD, Neushul M (1991) Photosynthetic physiology and chemical composition of spores of the kelps, Macrocystis pyrifera, Nereocystis luetkeana, Laminaria farlowii, and Pterygophora calformica (Phaeophyceae). J Phycol 27:26-34

Borowitzka M (1978) Plastid development and floridean starch grain formation during carposporogenesis in the coralline red alga Lithothrix aspergillium Gray. Protoplasma 95:217-228

Chapman ARO (1984) Reproduction, recruitment and mortality in two species of Laminaria on southwest Nova Scotia. J exp mar Biol Ecol 78:99-109

Christie AO, Evans LV (1962) Periodicity in the liberation of gametes and zoospores of Enteromorpha intestinalis Link. Nature 193:193-194

Doty MS (1967) Pioneer intertidal population and related vertical distribution of marine algae in Hawai'i. Blumea 15:95-105

Grace JB (1990) On the relationship between plant traits and competitive ability. In: Grace JB, Tilman D (eds) Perspectives on plant competition. Academic Press, Inc, San Diego, p 51-65

Grime JP (1979) Plant strategies and vegetation processes Wiley, London

Hoffmann AJ, Camus P (1989) Sinking rates and viability of spores from benthic algae in central Chile. J exp mar Biol Ecol 126:281-291

Inskeep WP, Bloom PR (1985) Extinction coefficients of chlorophyll $a$ and $b$ in $N, N$-dimethylformamide and $80 \%$ acetone. Plant Physiol 77:483-485

Jerlov NG (1968) Optical oceanography. Elsevier, Amsterdam

Jones WE, Babb MS (1968) The motile period of swarmers of Enteromorpha intestinalis (L.) Link. Br phycol Bull 3 . $525-528$

Kain JM (1964) Aspects of the biology of Laminaria hyperborea. J mar biol Ass UK 41:415-433

Kain JM, Norton TA (1990) Marine ecology. In: Cole KM, Sheath RG (eds) Biology of the red algae. Cambridge University Press, Cambridge, p 377-422

Littler MM, Arnold KE (1982) Primary productivity of marine macroalgal functional-form groups from southwestern North America. J Phycol 18:307-311

Littler MM, Littler DS (1984) Relationships between macroalgal functional form groups and substrata stability in a subtropical rocky intertidal system. J exp mar Biol Ecol 74: $13-34$

Matta JL, Chapman DJ (1991) Photosynthetic responses and daily carbon balance of Colpomenia peregrina: seasonal variations and differences between intertidal and subtidal populations. Mar Biol 108:303-313

McBride DL, Cole K (1971) Electron microscope observations on the differentiation and release of monospores in the marine red alga Smithora naiadum. Phycologia 10:49-61

McLachlan J, Bidwell RGS (1978) Photosynthesis of eggs, sperms, zygotes, and embryos of Fucus serratus. Can J Bot 56:371-373

Minitab Reference Manual (1991) Minitab Inc, PA, p 4-8

Moran R, Porath D (1980) Chlorophyll determination in intact tissues using $N, N$-dimethylformamide. Pl Physiol 65: $478-479$

Niesembaum RA (1988) The ecology of sporulation by the macroalga Ulva lactuca L. (Chlorophyceae). Aquat Bot 32: $155-166$

Olsen RR (1985) The consequences of short-distance larval dispersal in a sessile marine invertebrate. Ecology 66: $30-39$ 
Reed DC, Foster MS (1984) The effects of shading on algal recruitment and growth in a giant kelp forest. Ecology 65: $937-948$

Roughgarden J, Gaines S, Possingham H (1988) Recruitment dynamics in complex life cycles. Science 24:1460-1466

Santelices B (1990) Patterns of reproduction, dispersal and recruitment in seaweeds. Oceanogr Mar Biol A Rev 28: $177-276$

Sawada I (1978) Periodic fruiting of Ulva pertusa at three localities in Japan. Proc int Seaweed Symp 7:229-230

Smith CM, Alberte RS (1994) Characterization of in vivo absorption features of chlorophyte, phaeophyte and rhodophyte algal species. Mar Biol 118:511-521

Smith CM, Berry JA (1986) Recovery of photosynthesis after exposure of intertidal algae to osmotic and temperature stresses: comparative studies of species with differing distribution limits. Oecologia 70:6-12

This article was submitted to the editor
Smith GM (1947) On reproduction of some Pacific coast species of Ulva. Am J Bot 34:80-87

Steneck RS, Dethier MN (1994) A functional approach to the structure of algal-dominated communities. Oikos 69 : $476-498$

Thorson G (1950) Reproductive and larval ecology or marine bottom invertebrates. Am Nat 108:29-44

Tilman GD (1977) Resource competition between planktonic algae: an experimental and theoretical approach. Ecology 58:338-348

Tilman GD (1982) Resource competition and community structure. Princeton University Press, Princeton

Toth $R$ (1976) The release, settlement and germination of zoospores in Chorda tomentosa (Laminariales). J Phycol $12: 222-233$

Zar JH (1984) Biostatistical analysis, 2nd edn. Prentice-Hall Inc, Englewood Cliffs

Manuscript first received: August 12, 1994

Revised version accepted: April 4, 1995 